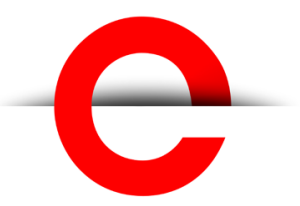

U T S

e PRES S
PORTAL Journal of

Multidisciplinary

International Studies

Vol. 13, No. 2

July 2016

Designing Futures in

Indonesia, Curated Works

Special Issue, Curated by

Alexandra Crosby.

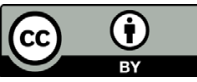

(C) 2016 by Cindy Lin and Andrew Moon. This is an Open Access article distributed under the terms of the Creative Commons Attribution 4.0 Unported (CC BY 4.0) License (https:// creativecommons.org/ licenses/by/4.0/), allowing third parties to copy and redistribute the material in any medium or format and to remix, transform, and build upon the material for any purpose, even commercially, provided the original work is properly cited and states its license.

Citation: Lin, C. and Moon, A. 2016. Negotiating Time: Design as Historical Practice. PORTAL Journal of Multidisciplinary International Studies, 13:2, 1-8. http://dx.doi. org/10.5130/portal.v13i2.5030

ISSN 1449-2490 | Published by UTS ePRESS I http://portal. epress.lib.uts.edu.au
CURATED WORK

\section{Negotiating Time: Design as Historical Practice}

\author{
Cindy Lin', Andrew Moon ${ }^{2}$ \\ 1 School of Information, University of Michigan, Ann Arbor \\ ${ }^{2}$ Department of Anthropology, The New School for Social Research, New York
}

Corresponding author: Cindy Lin, School of Information, University of Michigan, 4322 North Quad, 105 S. State St, Ann Arbor MI 48109-1285 USA. cindylkyaumich.edu

DOI: http://dx.doi.org/10.5130/portal.v13i2.5030

Article History: Received 20/06/2016; Revised 27/06/2016; Accepted 11/07/2016;

Published 09/08/2016

\begin{abstract}
In North Jakarta, the bulldozed remnants of the April 11 (2016) eviction of Kampung Pasar Ikan presented a a site of radical transformation and urban planning. The eviction was in part motivated by a Dutch-Indonesian alliance, to construct a 40 billion USD sea wall and reclaimed islands to prevent the city from slowly sinking. In this text we start by asking, how are people living in Pasar lkan responding to and enacting their own futures through repair? What does repair in a landscape of complete disrepair look like? And how is history both erased and enacted in this process? We then move to West Kalimantan where a DIY drone collective makes aerial drone technology and trains groups to map land that they say is vulnerable to incursions by resource developers. We ask, how is the forest located, recognized and constituted by these and other cartographic practices? Whose time and in what time are forest boundaries set and reset by mapping techqniques in West Kalimantan? How do these cartographies become artifacts that travel and influence how history is thought and practiced?
\end{abstract}

\section{Keywords}

History; time; design; repair; mapping; cartography; Indonesia 
U T S

e PRES S
Pasar Ikan

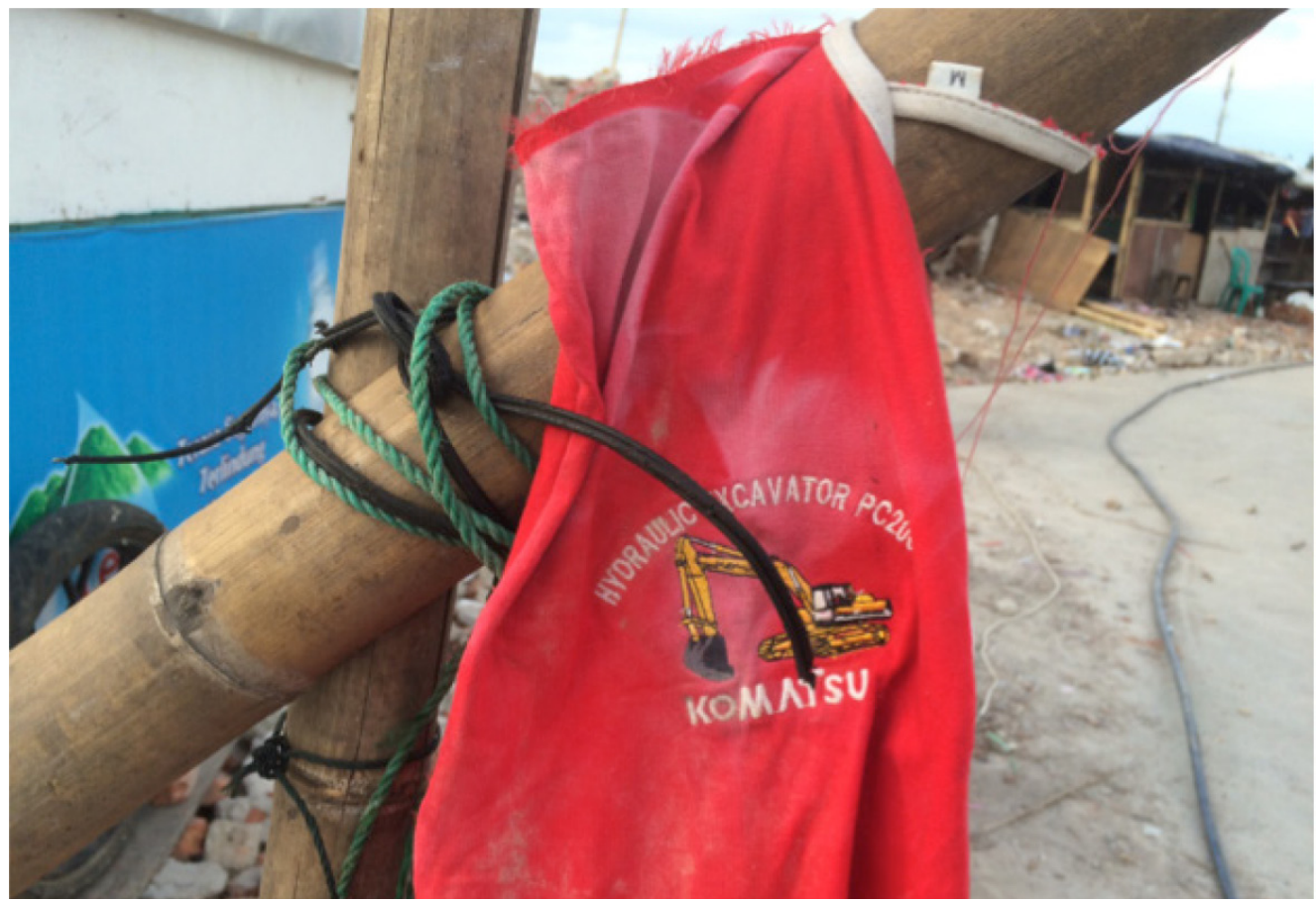

Figure 12016 ㄷ Andrew Moon

From Museum Bahari's leaning watchtower in North Jakarta, Kampung Pasar Ikan appeared clunky yet compact. The bulldozed remnants of the April 11 (2016) eviction aggregated in several rubble plateaus, presenting an image of Pasar Ikan as a site of radical transformation and urban planning. Indeed, the Jakarta Administration's decision to evict the residents of Pasar Ikan reads as an erasure of a particular history. The eviction is in part motivated by a Dutch-Indonesian alliance, to construct a 40 billion USD sea wall and reclaimed islands to prevent the city from slowly sinking. Residents of Pasar Ikan, however, have questioned their eviction, responding to and enacting their own futures through repair. But what does repair in a landscape of complete disrepair look like?

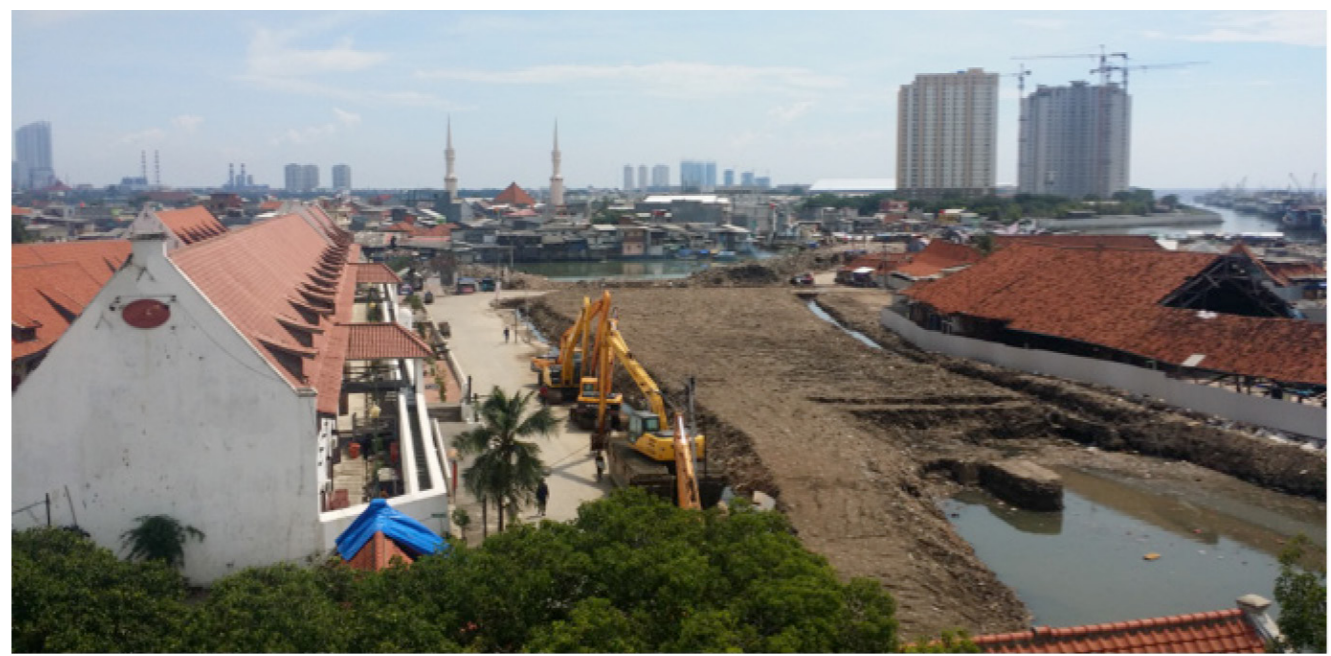

Figure 22016 @ Cindy Lin 
U T S

e PRES S
Approaching Pasar Ikan, past a sidewalk parallel to a heritage listed Colonial building, we asked Ibu Mirti, a mother of two, "What is electricity like here?” Ibu Mirti laughed, "Electricity is not enough for all of us now!" Ibu Mirti wrapped her baby in a dull-colored sarong, her eyes curious to our inquiry, yet distant. We learnt residents have begun repairing their own electricity supply with leftover poles, loose cables and a generator set; the assembly of cables draped and stretched across the topology of destroyed homes. Ibu Mirti explained why repair matters, "We make our own electricity supply as citizens in solidarity." For citizens in Pasar Ikan, repair revalues expertise collectively. In a landscape of infrastructural disassembly and violence wrought from above, citizens of Pasar Ikan may know best, adapting the existing topography to fit present needs. Speaking with Ibu Mirti and other citizens also brought to the fore questions of privilege and power - who decides and who designs.

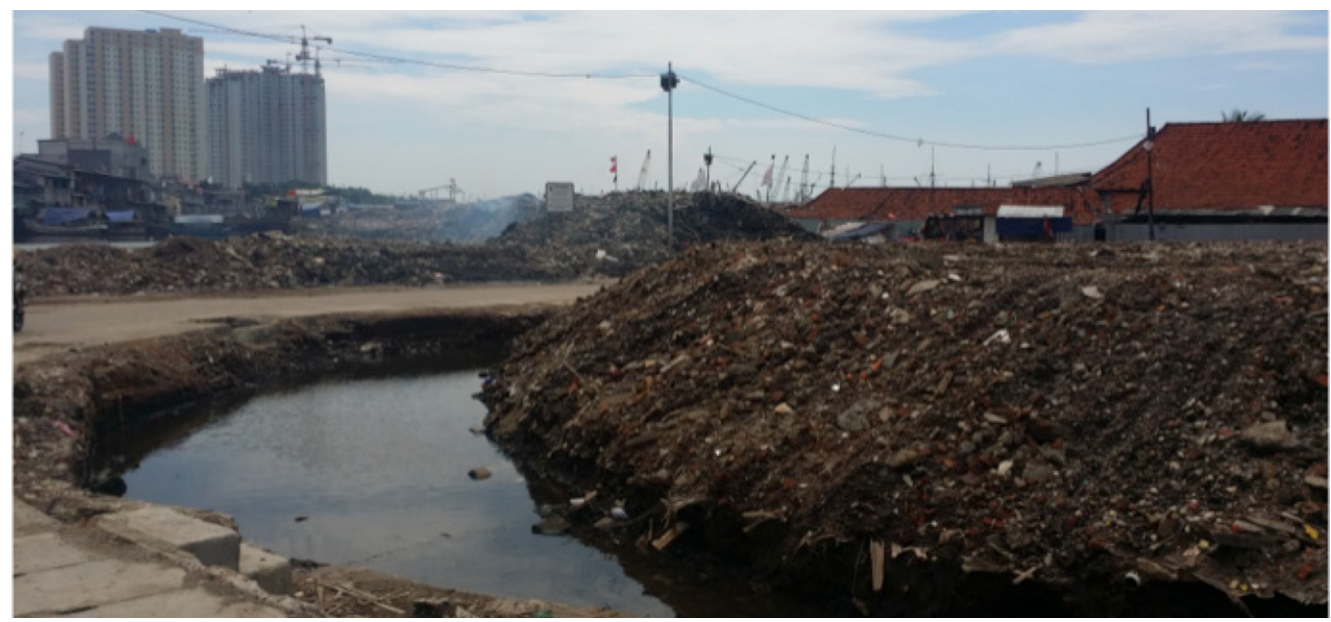

Figure 32016 @ Cindy Lin

While we walked slowly into Pasar Ikan, careful to sense out a path that felt appropriate underfoot, we stopped to speak with the owners of a makeshift warung (store), Ibu Cheche and her husband, Pak Irfan. They told us, "The electricity only runs from 9am to 4am, enough for us to light our warung up at night till 11pm."While we sipped on some sickly-sweet coffee mixes from their store, we asked if their warung was where we stood now before the eviction, "Yes, our warung was here. Do you remember that our previous warung is below our rumah (home)?"We smiled weakly, afraid that our engagement with the couple's history had fallen short. The warung sat on top of its old self; not quite the same, but still enough to remind them of a different territory in time.

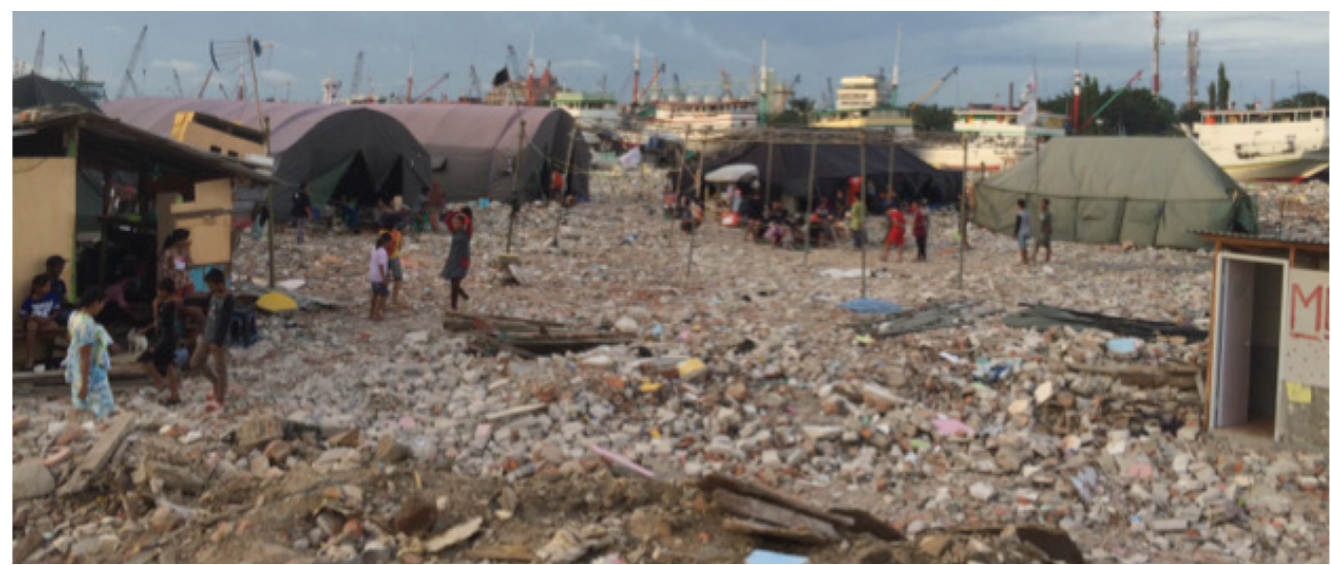

Figure 42016 @ Andrew Moon 
U T S

e P R E S S
The tent covering the warung spread out on top of unpolished bamboo poles. Two tables laid angular to one another with the front serving as a counter while the back was used for preparation. This meticulous arrangement of things sat on rubble that could have resembled it only a few months ago. Here, old and new worlds are entangled through repair. Ibu Cheche and Pak Irfan's warung demonstrates how places and knowledge are remade and redefined, however precarious, transient and un-scalable.

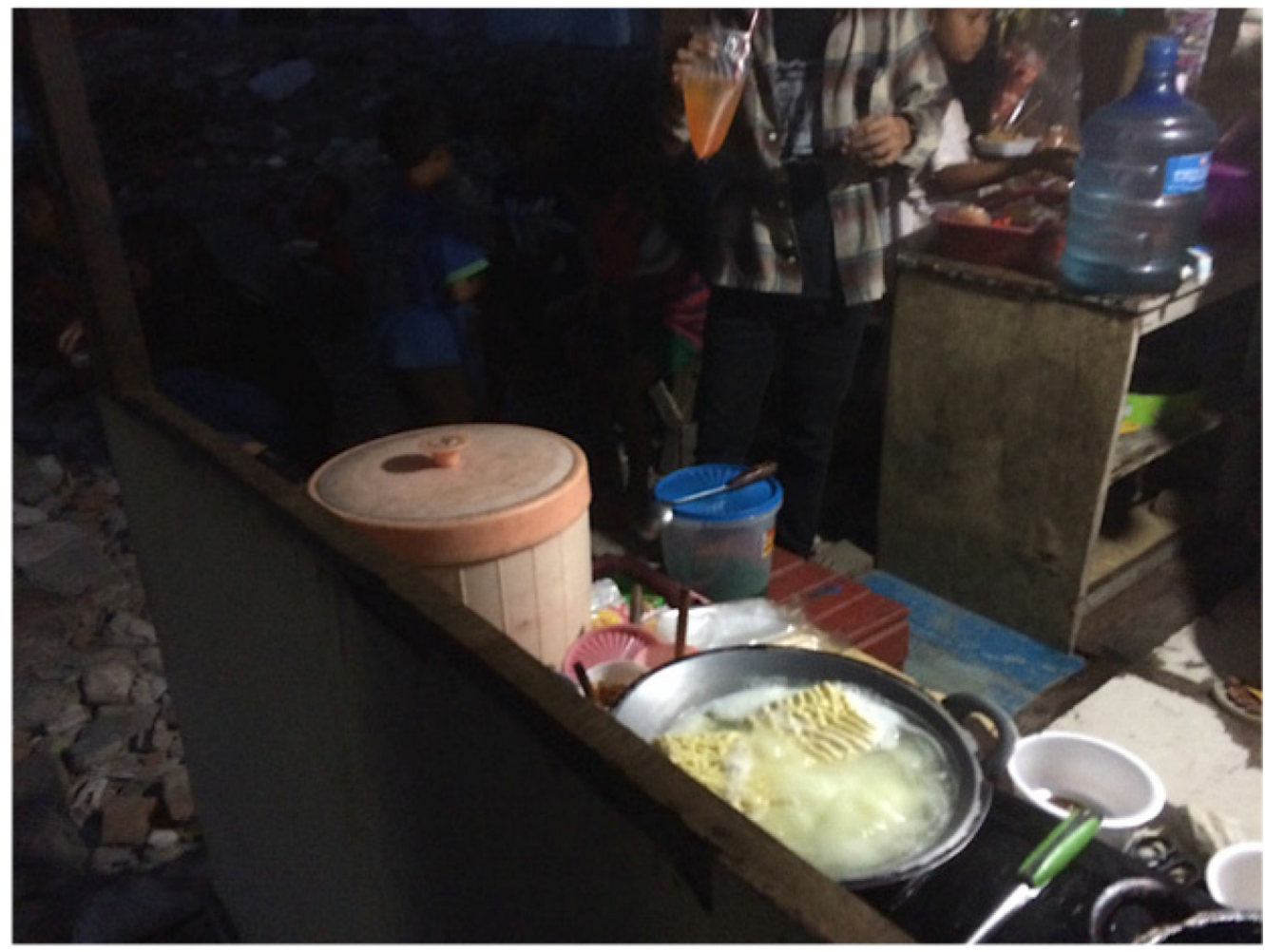

Figure 52016 @ Andrew Moon

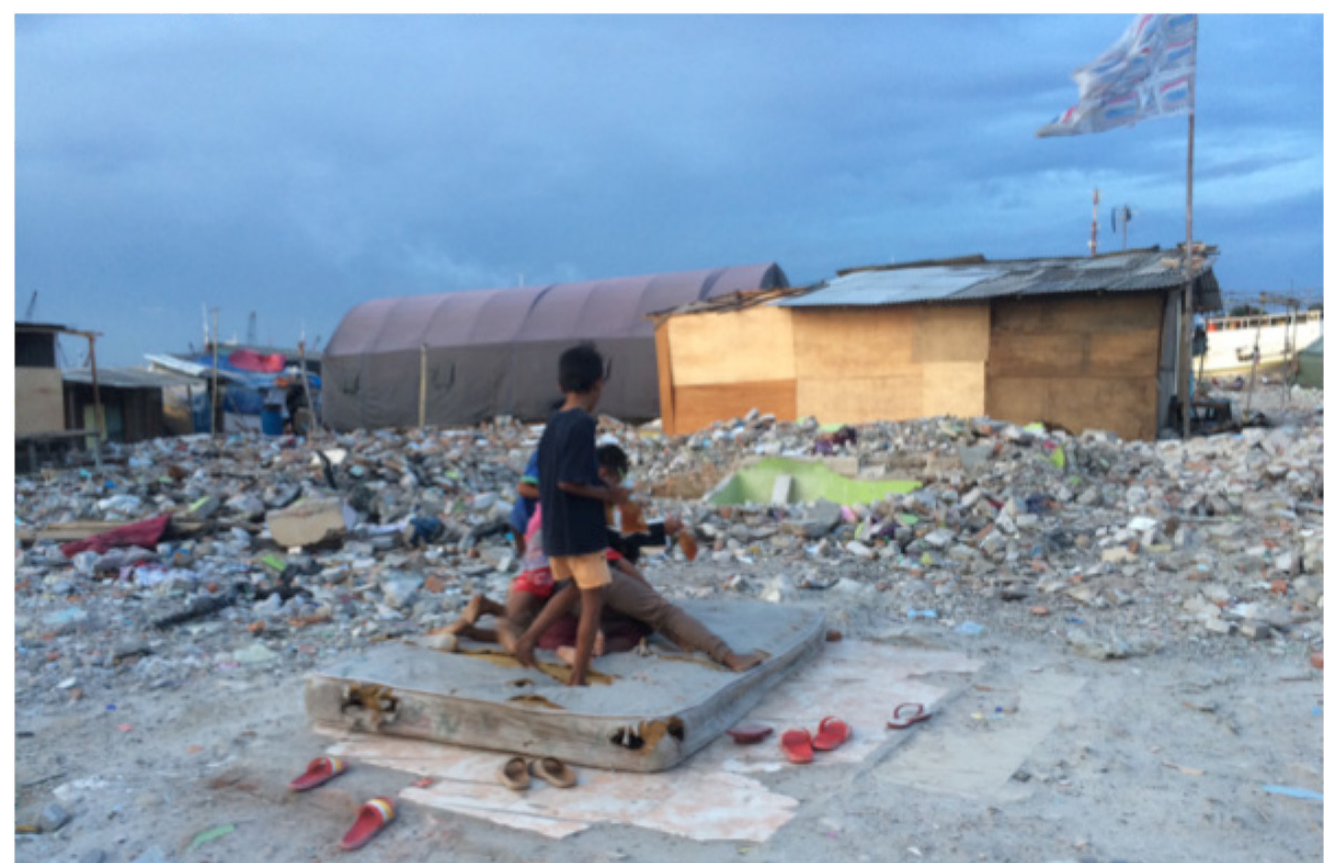

Figure 62016 ๑ Andrew Moon 
U T S

e PRES S
Pasar Ikan shows us how infrastructure is a creature that constantly evolves with repair. As Steve Jackson has argued, "[Repair] fills in the moment of hope and fear in which bridges from old worlds to new worlds are built, and the continuity of order, value and meaning gets woven, one tenuous thread at a time' (Jackson 2014, p. 223). Repair encourages us to take seriously the material interstices between past and future, showing how infrastructure demonstrates a historical legacy maintained to endure and retain the old but not quite. To repair then, is to question the premises of design knowledge and where it is located, foregrounding instead, particular practices, historicities and values that were previously denied their visibility and novelty.

\section{School of Drones}

How can a forest not be a forest? This question was posed in West Kalimantan while School of Drones (SOD), a DIY drone collective, discussed the different ways in which cartography is used to map areas vulnerable to and undergoing incursions by resource development. How do mapping practices by collectives like SOD, public interest groups and state agencies, and the non-human life they engage with, enact boundaries around the "forest"? Whose time and in what time are forest boundaries set and reset in West Kalimantan? How is the forest located, recognized and constituted by these cartographies in the present?

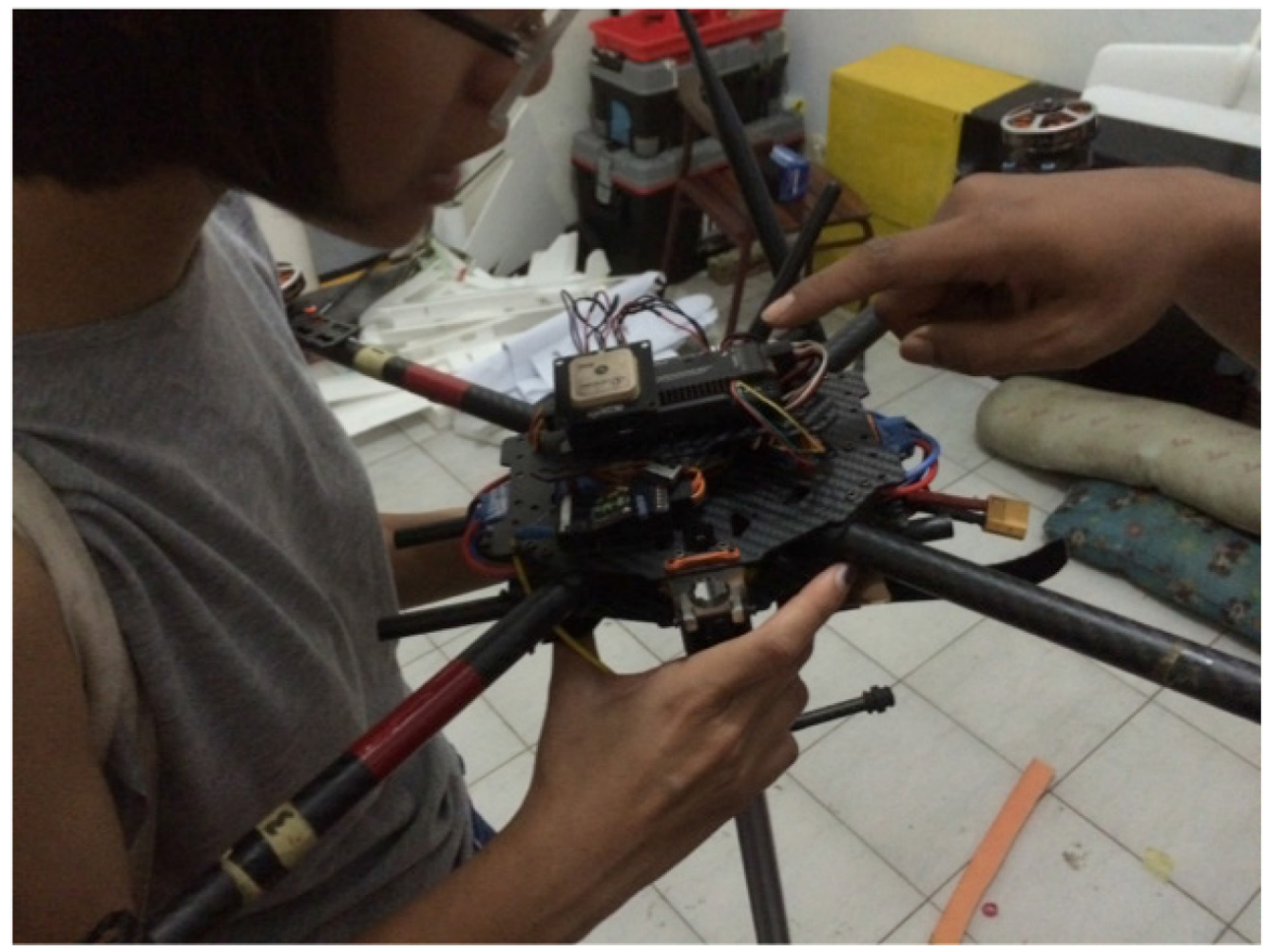

Figure 72016 ㄷ Andrew Moon

The wings and hulls of polystyrene drones hang from one wall while the connective tissue of circuit cables and camera mounts protrude from their core. An inventory of parts, motors, batteries, meters, carbon cut outs and wires, sit idle on the floor and an adjacent table. Who makes the maps we ask one drone maker, curious of their expertise and its location. "The 'local people' are trained." How are they trained? What language is taught to interpret these maps? "We leave that to them. You'd be amazed at how new coordinates appear in the sky." 
U T S

e PRES S

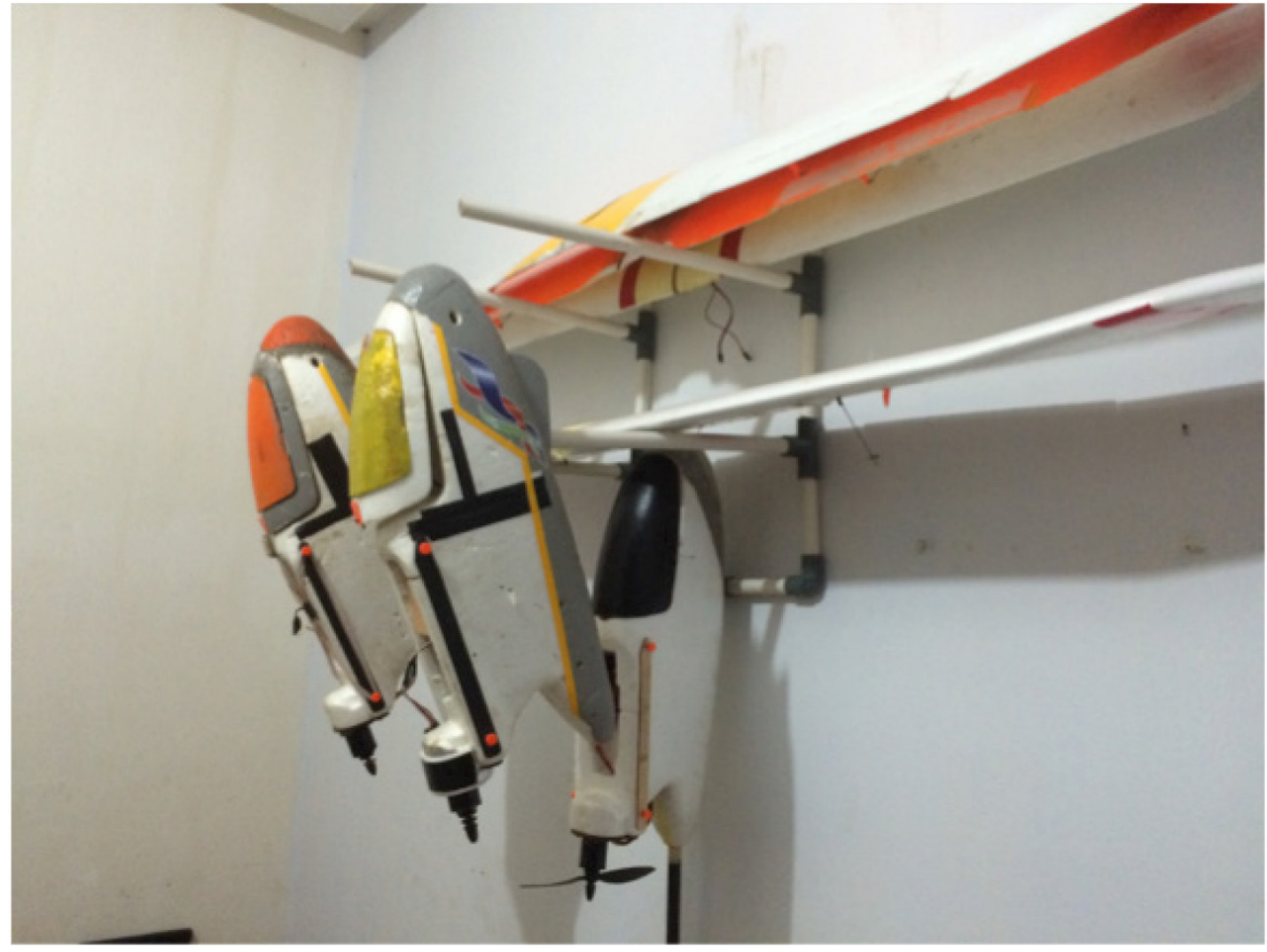

Figure 82016 ㄷ) Andrew Moon

Viewing the aerial image provoked awe as Kalimantan's landscape was given scale. We are told that SOD's maps identify "concession areas that exceed land available." How can that be so? The excess makes curious the ways in which boundaries are constituted by different mapping techniques. What does a boundary correspond with and what's absent in that correspondence? The collective's aerial work highlights the awkwardness of a place set upon by title, certification and concession, and the jurisdiction of foreign aid - those characteristics, we are told, have framed the forest.

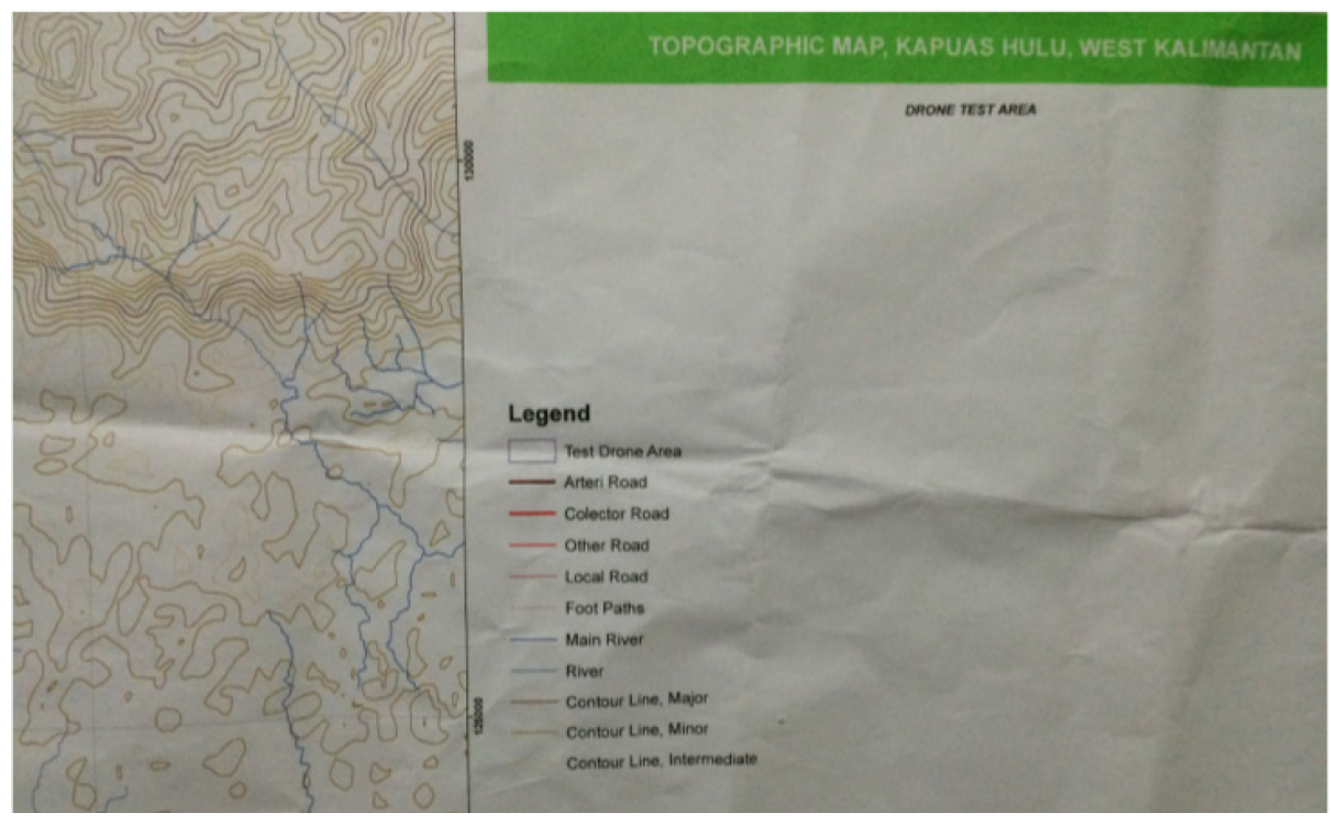

Figure 92016 ㄷ Andrew Moon 
U T S

e PRES S

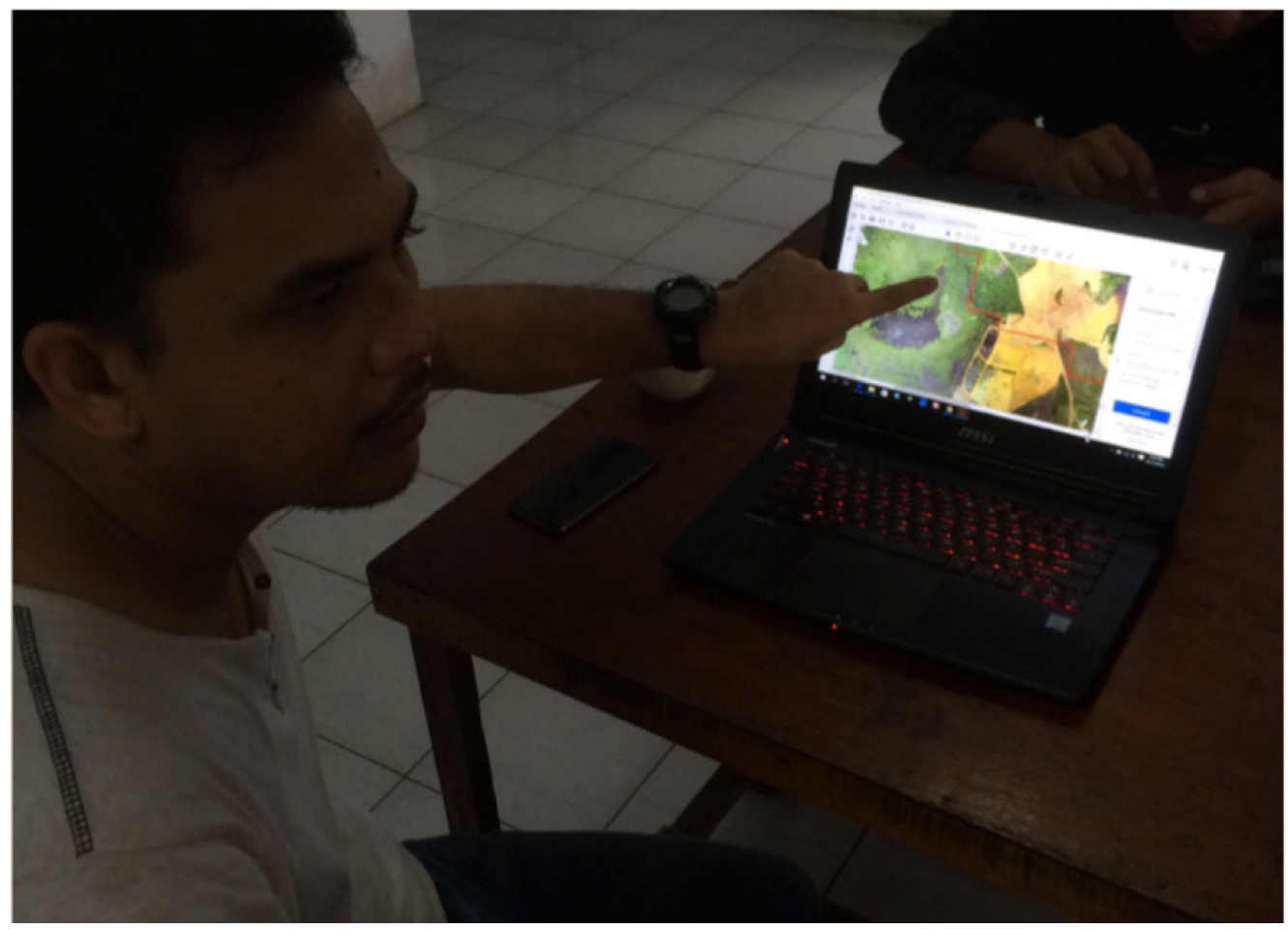

Figure 102016 (c) Andrew Moon

Beyond regarding the drone as a technological solution, we learnt from SOD that "not everything wants to be droned."We followed one drone maker to Kayong Utara in West Kalimantan where he described how the endangered Hornbill, a bird whose qualities are valued by Traditional Chinese Medicine, would be allergic to aerial interference. Looking out over the forest canopy during a late afternoon trek, we observed and listened to the Hornbill and other animal life, marking, if you will, boundaries of their own. The drone maker's concern was nuanced, highlighting a commitment not to the drone technology itself, but to the contingent nature of mapping and how other boundaries of place and time are negotiated and constituted.

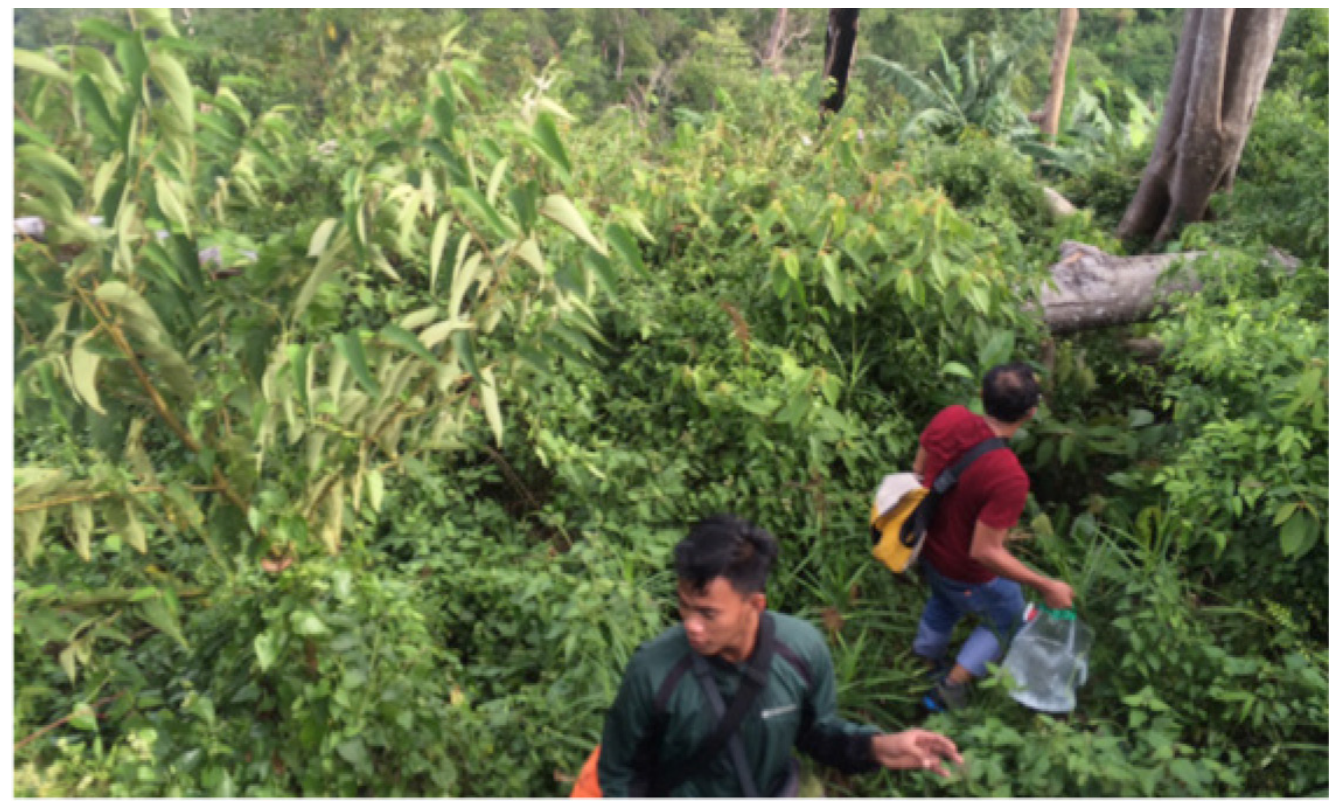

Figure 112016 @ Andrew Moon 
U T S

e PRES S

Anthropologist Lucy Suchman has argued that to understand how artifacts are arranged, in this case the forest boundaries in West Kalimantan, "requires locating an always more extended network of relations, arbitrarily cut through practical, analytical and/or political acts of boundary making" (Suchman 2007, p. 285). In the work of SOD, we encounter maps that emerge from these arbitrary cuts, not just their own, but from the many actors they engage with, and the interpretations, negotiations, movements, and interests that interact with their work. In this sense SOD's maps are important not because they deny or confirm boundaries enacted by public interest certification, company concession, small holders and non-human life, but because they highlight how the incommensurability of these frontiers in West Kalimantan can enable pathways to know and care for a time and place that are always in the making.

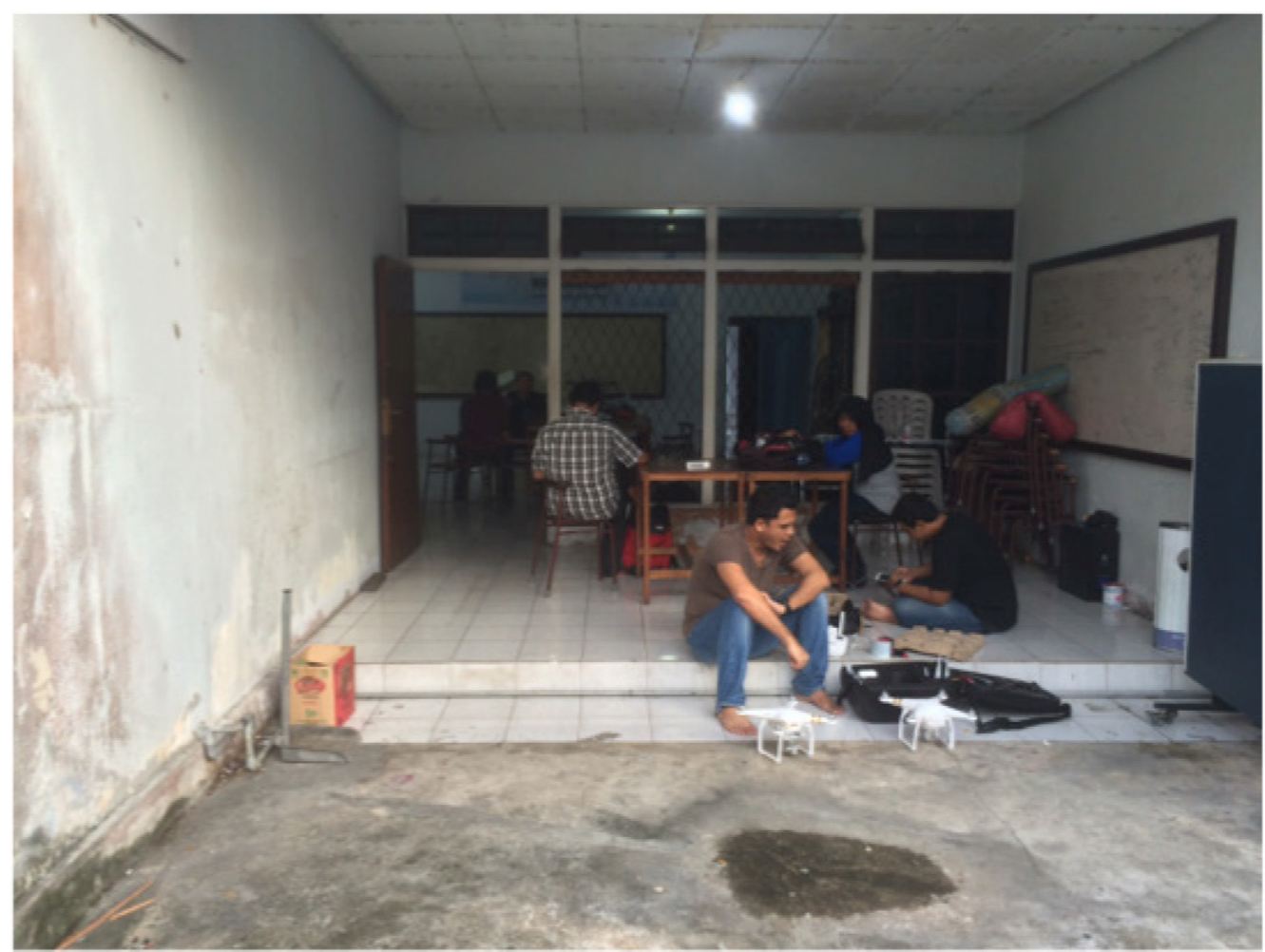

Figure 122016 @ Andrew Moon

\section{References}

Jackson, S.J. 2014, 'Rethinking Repair,' in Media Technologies: Essays on Communication, Materiality, and Society, eds T. Gillespie, P. J. Boczkowski \& K. A. Foot. MIT Press, Massachusetts: 221-237

Suchman, L. 2007, Human-Machine Configurations.Cambridge University Press, Cambridge 